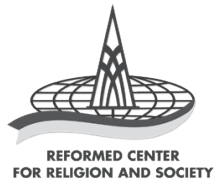

Societas Dei: Jurnal Agama dan Masyarakat

Vol. 7, No. 2 (October 2020): 173-196

http://societasdei.rcrs.org/index.php/SD/issue/archive

p-ISSN: 2407-0556; e-ISSN: 2599-3267

DOI: $10.33550 /$ sd.v7i2.151

Received: 6 April 2020

Revised: 16 September 2020

Accepted: 17 September 2020

\title{
KESAKSIAN IMAN DALAM DIALOG INTERRELIGIUS DAN TEOLOGI INTERKULTURAL
}

\section{WITNESS OF FAITH IN INTERRELIGIOUS DIALOGUE AND INTERCULTURAL THEOLOGY}

\author{
Edy Syahputra Sihombing \\ Program Studi Ilmu Filsafat, \\ Universitas Katolik Parahyangan, Bandung \\ inovio1@gmail.com
}




\begin{abstract}
:
The witness of faith is an important element in interreligious dialogue to nourish the existence of theology in intercultural contexts. But dialogue tends to be understood as merely sharing truth information and doctrines in various religions. Such model dialogue is actually not relevant in religious plurality. On the other hand, there are challenges to creating dialogue, including: arrogance, closed attitudes, and claims of truth absolutism. Such a situation does not foster theology in an intercultural context. Humility is the key to dialogue, and the witness of faith plays an important role in nourishing theology in intercultural contexts. In interreligious dialogue, the important witness of faith today is living and practicing the authentic teachings of every religion, such as living in peace, harmony of fraternity, building wisdom of love, and creating justice. This paper will explore the significance of faith witnessing in interreligious dialogue and intercultural theology with literature research methods to offer implementative recommendations.
\end{abstract}

Keywords: faith witness; dialogue; interreligious; intercultural; theology.

\begin{abstract}
Abstrak:
Kesaksian iman adalah unsur penting dalam dialog interreligius untuk menyuburkan eksistensi teologi dalam konteks interkultural. Akan tetapi dialog cenderung sekadar berbagi informasi kebenaran dan doktrin dalam berbagai agama. Dialog model demikian sesungguhnya tidak relevan dalam pluralitas agama. Di sisi lain, ada tantangan untuk menciptakan dialog, di antaranya: sikap arogansi, sikap tertutup, dan klaim absolutisme kebenaran. Situasi demikian tidak menyuburkan eksistensi teologi dalam konteks interkultural. Kerendahan hati adalah kunci berdialog, dan kesaksian iman berperan penting menyuburkan eksistensi teologi dalam konteks interkultural. Dalam dialog interreligius, kesaksian iman yang penting saat ini adalah menghidupi dan melakukan ajaran autentik dari setiap agama, seperti: hidup dalam perdamaian, persaudaraan yang harmonis, membangun kebijaksanaan berdasarkan kasih, dan menciptakan keadilan. Tulisan ini akan mengeksplorasi signifikansi kesaksian iman dalam dialog interreligius dan teologi interkultural menggunakan metode penelitian literatur yang memberikan tawaran rekomendasi implementatif.
\end{abstract}

Kata-kata Kunci: kesaksian iman; dialog; interreligius; interkultural; teologi. 


\section{Pengantar}

Ada beberapa latar belakang mengapa dialog interreligius saat ini penting untuk dilaksanakan dalam konteks pluralitas agama. Misalnya, paradigma eksklusivisme dalam agama yang dianggap tidak lagi relevan dalam konteks multireligiusitas, kepentingan agama-agama dalam rangka keterlibatan dalam perjuangan atas kemanusiaan, dan dialog yang dapat menjadi ruang saling memenuhi dan saling belajar di antara berbagai tradisi agama. Di sisi lain, signifikan sebagai paradigma dalam menafsirkan data yang berkaitan dengan keragaman agama-agama.

Thomas Kuhn, misalnya, telah berusaha mengubah arah paradigma saintifik secara radikal dengan konsep pergeseran paradigma (paradigm shift) sebagai pemandu arah sebuah cara pandang yang baru terhadap kebenaran. Dialog interreligius juga merupakan sebuah paradigma yang memandu arah dalam usaha bersama agama-agama untuk hidup rukun dan saling membangun dalam konteks plural. Dengan kata lain, dialog menjadi penting karena membuka peluang terciptanya sebuah paradigma baru dalam interaksi agama yang berbeda. ${ }^{1}$

Dalam konsepnya, Thomas Kuhn berangkat dari gagasan bahwa perlu ada revolusi baru dalam ilmu pengetahuan agar dapat berkembang menemukan solusi yang tepat terhadap masalah yang muncul dalam realitas. Revolusi itu dimulai dengan usaha pencarian model struktur teoretis baru atau dalam bahasa Thomas Kuhn disebut sebagai paradigma baru. Gagasan paradigma baru menumbuhkan kesadaran bahwa kita hidup dan berada di dunia yang senantiasa berubah dalam pemahaman terhadap realitas. $^{2}$

Saat ini, gagasan Kuhn relevan dalam berbagai ilmu pengetahuan termasuk teologi. Perjumpaan tradisi religius dalam konteks yang plural memuat tendensi munculnya anggapan bahwa tujuan dialog interreligius adalah mewartakan pewahyuan mengenai kebenaran suatu agama kepada agama lain. Sebenarnya tujuan seperti ini sah, namun berpotensi menghilangkan makna esensial dari dialog antaragama yang sebenarnya bertujuan untuk saling bersaksi dan saling menumbuhkan. ${ }^{3}$ Selain itu, dialog cenderung dipandang sekadar melakukan pertukaran informasi tentang agama dan tradisinya dalam rangka mewujudkan sikap saling menghormati maupun sikap kolaboratif untuk menciptakan perdamaian di antara agama-agama.

\footnotetext{
Cathrine Cornille, Interreligious Dialogue (Chichester, UK: John Wiley \& Sons, 2013), 10-11.

David J. Bosch, Transforming Mission: Paradigm Shifts in Theology of Mission (Maryknoll, New York: Orbis Books, 2011), 167-168.

Ecumenical \& Interreligious Perspectives: Globalization in Theological Education, Russel E Richey ed. (Nashville: QR Books, 1992), 96-97.
} 
Kecenderungan demikian sekadar mengantarkan relasi agama-agama dan tradisi religius yang berbeda ke wilayah sinkretisme. ${ }^{4}$ Relasi yang bersifat sinkretisme berpotensi menjadi totaliter di pihak mereka yang berpretensi mendamaikan dengan mengabaikan nilai-nilai lebih luhur yang tidak mereka kuasai. $^{5}$

Dalam tulisan ini, istilah yang digunakan adalah dialog interreligius atau dialog antaragama dengan tujuan setiap agama dapat saling berjumpa meski perlu ditegaskan bahwa yang berdialog adalah para pemimpin dan juga para penganutnya. Dialog interreligius adalah sebuah perjumpaan dalam keterbukaan yang konstruktif di antara semua pihak dalam konteks pluralitas agama. Tujuannya adalah agar dapat bersama-sama mencari dan menemukan kebenaran serta bertumbuh dalam kebenaran. Substansi keterbukaan mengandung sikap teguh dalam keyakinan sendiri yang terdalam dengan jelas dan gembira, sementara pada saat yang sama juga terbuka untuk memahami tradisi-tradisi dan pendirian keagamaan dari pihak lain dan mengetahui bahwa dialog dapat memperkaya pihak masing-masing. ${ }^{6}$ Dialog model demikian diyakini dapat berjalan dengan baik melalui kesaksian.

Stephen Tong menegaskan bahwa pengertian dan pengenalan akan Tuhan sangat penting terutama dari teologi yang mengantar pada pengenalan dan pengetahuan akan Allah. Orang yang mengetahui teologi tidak boleh tidak pergi menjadi saksi dan orang yang menjadi saksi tidak boleh tidak memiliki dasar teologi. ${ }^{7}$ Artinya, pengenalan akan iman dan tentang Allah dalam tradisi masing-masing harus sungguh-sungguh dipahami, dikenali, dan dialami agar dapat berbuah kesaksian yang transformatif dan saling memenuhi satu sama lain. Dengan kata lain, kesaksian yang berdampak bagi kerukunan dan harmoni pluralitas agama sangat ditentukan oleh pemahaman yang utuh dan mendalam tentang tradisi dan ajaran autentik tentang agama masing-masing.

Kesaksian dapat teraplikasi dan terwujud dalam bentuk tindakan komunal maupun personal berdasarkan keyakinan yang diimani dan

Sinkretisme berasal dari bahasa Yunani sun dan kretein dalam bahasa Inggris syncretism, yang berarti menyatukan dua kota di Kreta untuk melawan yang ketiga. Dalam konteks teologi, sinkretisme berarti setiap usaha untuk mendamaikan atau bahkan mencampurkan prinsip atau praktik yang berbeda atau bahkan yang sebenarnya tidak terdamaikan. Sinkretisme yang biasanya hanya pada tingkat permukaan dan mudah hilang itu dapat terjadi antara agama-agama, filsafat, dan bahkan dalam kekristenan sendiri. George Callixtus (1586-1656) adalah tokoh pertama yang mencoba mengadakan sinkretisme ekumenis dalam lingkup luas. Lih. Gerald O'Collins \& Edward G. Farrugia, Kamus Teologi (Yogyakarta: Kanisius, 1996), 298.

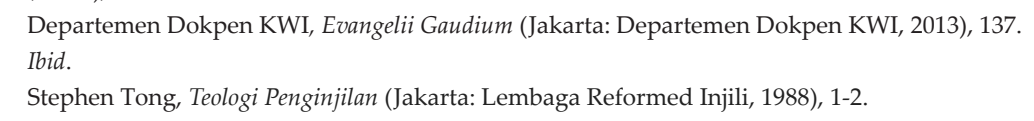


dipraktikkan dalam konteks kemanusiaan untuk saling menginspirasi, meneguhkan, dan menumbuhkan semua pihak. Hal lain yang perlu ditekankan adalah pencarian kebenaran satu pihak saja tidak akan bekerja maksimal dalam konteks dialog. Pencarian bersama-sama akan menemukan hasil yang lebih baik.

Kerendahan hati dalam berdialog di dalam konteks pluralitas agama diperlukan untuk mencapai hasil yang baik. Artinya, dialog demikian mengandaikan setiap pihak telah sungguh mendalami segala aspek di dalam agama sendiri bahkan agama lain sekaligus mengandaikan kemampuan untuk menerima kritik atas agama sendiri dan melihatnya sebagai langkah kematangan iman. Prinsip dasarnya adalah bahwa setiap tradisi agama mengomunikasikan dan memberikan kesaksian bagaimana mencari, menemukan, dan menaati atau mengikuti Allah dengan setia. Setiap kelompok umat dapat saling membantu untuk beriman secara lebih mendalam. To be religious is to be interreligious. ${ }^{8}$

Studi dan penelitian tentang dialog dalam kaitannya dengan kesaksian iman telah dilakukan sebelumnya oleh Yohanes Prihala dan Kritsno Saptenno. Dalam studi tersebut dipaparkan, berdasarkan inspirasi dari Calvin E. Shenk, tugas kesaksian iman dalam agama mendesak diperlukan dalam konteks pluralitas dan globalisasi. Dalam perjumpaan dengan agama lain dialog menjadi salah satu bentuk kesaksian iman. Di dalam kekristenan, misalnya, dialog dalam bingkai kesaksian iman memiliki pendasaran biblikal dalam peristiwa inkarnasi Yesus. Peristiwa inkarnasi Yesus yang hadir ke dunia adalah sebuah peristiwa Tuhan yang hadir dan "berdialog" dengan manusia, mengomunikasikan diri, dan mengasihi manusia. ${ }^{9}$ Berbeda dengan kajian hasil studi tersebut, artikel ini mengkaji kesaksian iman dalam dialog sebagai dasar paradigma agama-agama melakukan misi di tengah konteks pluralitas dan interkultural agar agama yang plural dapat tetap hidup berdampingan dalam misi dan kesaksian iman.

Dialog antarumat beragama berperan penting dalam usaha menciptakan kerukunan di tengah konteks pluralitas agama. Kita tahu bahwa sampai saat ini kita masih merasakan ketegangan relasi antarkomunitas agama, khususnya di Indonesia, yang dapat berujung pada kekerasan. ${ }^{10}$

\footnotetext{
8 J.B. Banawiratma \& Zainal Abidin Bagir, ed., Dialog Antarumat Beragama: Gagasan dan Praktik di Indonesia (Jakarta: Mizan Publika, 2010), 17.

9 Yohanes Parihala \& Kritsno Saptenno, "Dari Kesaksian Iman ke Simbiosis Agama: Mininjau Konsep Dialog Calvin E. Shenk Bagi Perjumpaan Islam-Kristen di Maluku," dalam Religious: Jurnal Studi Agama-Agama dan Lintas Budaya 4, no. 2 (Mei, 2020): 104-114.

10 Zainal Abidin Bagir, Kerukunan dan Penodaan Agama Alternatif Penagangan Masalah (Yogyakarta, CRCS Universitas Gadjah Mada, 2017), 4-10. Laporan Center for Religion and Cross-Cultural Studies (CRCS) Universitas Gadjah Mada, pada tahun 2017 kehidupan beragama di Indonesia menunjukkan bahwa ujaran publik, tindakan yang menyinggung kelompok agama tertentu, ujaran kebencian, provokasi, dan
} 
Misalnya, menyangkut masalah pembangunan rumah ibadah masih muncul hampir setiap tahun, atau bahkan pembongkaran rumah ibadah. Demikian juga, ketegangan yang bersumber dari masalah hubungan antar maupun intrakelompok agama di Indonesia. Contohnya adalah diskriminasi yang masih dialami penganut agama-agama tidak resmi (di luar enam agama yang diakui secara hukum di Indonesia) maupun aliran kepercayaan yang masih mendapat diskriminasi secara hukum. Dalam situasi demikian, dialog sangat mendesak untuk meredakan ketegangan dan berbagai masalah yang masih dialami terkait dengan relasi antarumat beragama yang dapat menimbulkan diskriminasi dan kekerasan. ${ }^{11}$

\section{Metode Penelitian}

Dalam mengeksplorasi tema kesaksian iman dalam dialog interreligius dan teologi interkultural, penulis menggunakan metode penelitian literatur yang bersifat eksploratif-kualitatif. Metode ini bertujuan untuk memaparkan masalah yang muncul dalam konteks hidup bersama di tengah keragaman agama, serta memberikan kerangka berpikir mengenai upaya perwujudan dialog yang berdaya transformatif bagi realitas tersebut.

Penulis mengekplorasi literatur bertema signifikansi dialog dan kesaksian iman dalam konteks pluralitas agama. Selain itu, penulis menggali data-data pendukung terkait dengan masalah dan potensi konflik dalam konteks pluralitas agama yang menjadi latar belakang pentingnya dialog. Dalam usaha memberi jawaban atas masalah tersebut, penulis mengeksplorasi dan melakukan studi pustaka tentang dialog interreligius dan kesaksian iman serta menganalisis secara naratif untuk memberikan rekomendasi bagi masalah tersebut. Berdasarkan eksplorasi tersebut, tema tulisan ini penting untuk menjadi bahan refleksi bersama terkait dengan dialog dan kesaksian bersama.

Dalam mencapai harapan tersebut, tulisan ini dimulai dengan mengeksplorasi substansi kesaksian berkaitan dengan misi dan dialog interreligius. Selain itu, penulis memperlihatkan pertentangan yang muncul antara konsepsi misi dalam agama dan juga tuntutan akan pentingnya dialog interreligius sebagai ruang kesaksian satu sama lain. Di dalam bagian berikutnya, penulis akan mengeksplorasi tentang hakikat dari kesaksian dalam teologi agama-agama yang niscaya dimiliki setiap agama namun juga dapat menjadi sumber potensi konflik.

hasutan yang berpotensi menimbulkan tindakan kekerasan menjadi masalah genting dan mengakibatkan ketegangan antarumat beragama. Beberapa kasus yang muncul misalnya, kasus Meliana di Tanjung Balai Sumatra Utara, kasus mantan Gubernur DKI Jakarta Basuki Tjahaja Purnama, kasus Rizieq Sihab dan Munarman, kasus Aking Saputra di Karawang dan dr. Otto Rajasa di Balikpapan.

11 Ibid., 14-16. 
Peran kesaksian dalam teologi interkultural dan teologi perbandingan agama merupakan bahasan selanjutnya. Bahasan ini akan mengekplorasi bagaimana teologi yang hidup dalam dinamika konteks interkultural berdaya transformasi bagi realitas. Berbeda dengan subbab sebelumnya, bahasan ini akan lebih melihat bagaimana peran kesaksian dalam teologi yang hidup dalam konteks interkultural. Dalam hal ini, teologi harus berusaha menerjemahkan terus-menerus kesaksian-kesaksian yang termuat di dalam pengalaman iman dan di dalam paradigma teologis ke dalam dunia kultural manusia yang terus berubah agar tetap memiliki daya transformatif bagi konteks di mana teologi dan kesaksian itu hadir. Di dalam bahasan ini juga akan dieksplorasi teologi perbandingan. Teologi perbandingan agama tidak hanya menekankan pembelaan iman, melainkan juga keterbukaan pada pihak lain yang dapat mencerahkan dan memperkaya pemahaman sebuah agama. Informasi ini penting untuk menekankan pentingnya perjumpaan, dialog, dan saling bersaksi dalam pluralitas agama.

Di bagian akhir, penulis akan mengekplorasi signifikansi kesaksian dan dialog interreligius agar saling merangkul satu sama lain dalam menghadapi berbagai masalah yang dihadapi manusia. Penulis menegaskan bagaimana konteks kemanusiaan menjadi pemersatu keragaman agama untuk saling membela dan menciptakan peradaban baru yang ditandai dengan kedamaian. Dalam tulisan ini, penulis mengakui masih terdapat kelemahan dan beberapa hal yang tidak dapat dimuat lebih komprehensif. Oleh sebab itu, penulis terbuka terhadap masukan dan kritik.

\section{Kesaksian di dalam Misi dan Dialog Interreligius}

Pemahaman kesaksian yang berkait dengan misi dan dialog masih menjadi ajang perdebatan dalam tradisi kristiani saat ini. Teolog pluralis seperti Paul Knitter berpendapat bahwa perbedaan antara misi dan dialog perlu dihilangkan sebab keduanya memiliki substansi agenda yang sejalan. ${ }^{12}$ Sementara itu teolog lainnya seperti Jacques Dupuis mengkritik pandangan tersebut dan mengacu pada magisterium gereja Katolik ${ }^{13}$ yang dipaparkan dalam ensiklik Redemptoris Missio $^{14}$ yang mencantumkan

12 Frans Jozef Servaas Wijsen \& Peter Nissen, Mission is Must: Intercultural Theology and the Mission of the Church (New York \& Amsterdam: Rodopi, 2002), 53-55.

13 Magisterium Gereja Katolik adalah struktur kepemimpinan dalam Gereja Katolik yang mempunyai tugas mengajarkan injil secara berwibawa atas nama Yesus. Semua orang beriman yang dibaptis dan dipimpin oleh Roh Kudus dalam arti tertentu mempunyai tanggungjawab kenabian untuk mewartakan kabar gembira mengenai Yesus Kristus. Orang-orang yang mempunyai kewenangan untuk mewartakan dan mengajar secara resmi, ikut ambil bagian dalam magisterium gereja. Orang Katolik percaya bahwa kuasa mengajar ini dimiliki oleh seluruh dewan para uskup dalam kesatuan dengan uskup Roma.

14 Ensiklik Redemptoris Missio adalah dokumen kepausan gereja Katolik yang dikeluarkan oleh Paus Yohanes Paulus II tanggal 7 Desember 1990. Isi dokumen ini membahas topik tentang kebutuhan 
penekanan tentang perlunya menjaga perbedaan pandangan tersebut. Misi tidak begitu saja dapat direduksi menjadi sekadar dialog, walaupun dengan alasan yang berbeda-beda.

Ketika dilihat dari perspektif peran kesaksian, kita akan menemukan argumen pro dan kontra tentang hubungan antara misi dan dialog. Penekanan pada perbedaan keduanya akan mereduksi dialog interreligius menjadi sekadar pertukaran informasi atau penerjemahan umum dari studi agama-agama. Bila menyamakan keduanya, itu berarti menyoroti elemen kesaksian tidak hanya pada isinya (contents) tetapi juga pada kebenaran keyakinan pihak lain dan membawa semangat dalam suasana dialog. Di lain pihak, misi tanpa dialog adalah sesuatu yang tidak mungkin karena hanya akan menegasikan prinsip yang tulus dan konstruktif dari keberagaman yang ada. Keduanya tetap saling berkaitan dan saling meresapi (interpenetrate) tetapi tetap dapat dibedakan. ${ }^{15}$

Jika kita mampu menerjemahkan dan menjelaskan perbedaan antara pewartaan dan dialog maka kita semakin menghargai perbedaan. Aspek perbedaan bukan pusat dari kesaksian, melainkan menjadi model kesaksian di antara agama-agama yang terlibat dalam dialog. Dengan pendekatan bersifat fenomenologis dan deskriptif, kesaksian yang berasal dari pengalaman dan keyakinan suatu agama tetap dijaga dan terdorong untuk membagikannya kepada pihak lain. Pendekatan fenomenologi agama adalah metode berpikir ilmiah, yang berlatar belakang filsafat, untuk menalar fenomena agama yang bersandar pada pengalaman kehidupan beragama. Dengan kata lain, fenomenologi agama adalah sebuah metode pendekatan untuk memahami agama yang tampak dalam berbagai manifestasinya berkaitan dengan sikap dan perilaku manusia dalam setiap upaya mengalami dan menghadirkan Tuhan dalam kesadaran eksistensialnya. ${ }^{16}$

Pendekatan fenomenologi agama, seperti yang ditekankan Nathan Söderblom, perlu dimulai dari konsep mengenai yang suci. Baginya kesucian adalah dunia besar dalam agama, bahkan lebih esensial dari ide tentang Tuhan atau juga dengan istilah yang dirumuskan Rudolf Otto mengenai sensus numinus (pengalaman akan yang suci). ${ }^{17}$ Penekanan pada titik berangkat ini diharapkan mampu merangkul semua agama yang ada di dunia, bahkan yang tidak memiliki konsep Tuhan sekalipun. Bagi para fenomenolog, pendekatan fenomenologi yang dipakai dalam dialog interreligius

\footnotetext{
mendesak dalam kegiatan perutusan gereja.

15 Peter Admirand, "Mission in Remission," dalam Concilium Volume 1 (London: SCM Press, 2011), 100.

16 Peter Conolly, ed., Ragam Pendekatan Studi Agama (Medan: Bina Media Perintis, 2007), 98-109.

7 Ibid., 115-116.
} 
perlu menekankan pemurnian prasangka buruk terhadap yang lain, serta berusaha melihat apa yang sesungguhnya ada dalam setiap agama. Artinya, para pelakunya harus mampu melihat esensi fenomena agama tersebut secara obyektif. Dengan itu, dialog membantu pesertanya untuk menjadi rendah hati dan membuka ruang refleksi berdasarkan refleksi agama lain.

Dalam dialog, kesaksian adalah pokok penting yang bahkan melampaui setiap warta khusus, yang juga memang perlu diikutsertakan. Kesaksian tentang iman dan paradigma kebenaran dari setiap agama tidak boleh dianggap sebagai sebuah rumusan keyakinan yang sudah baku bagi yang lain, melainkan juga ada usaha menyusun ulang kepercayaan tersebut melalui pertanyaan yang lebih besar dan jawaban yang dapat ditawarkan. Sikap seperti ini dapat memancarkan sinar baru bagi agama lain apabila dialog dipahami sungguh sebagai ruang bersaksi yang unik. Kesaksian dalam dialog seperti ini dapat membuat orang lain merasa tertantang, dan merasakan ketidakmapanannya dalam beriman, bahkan merasa tidak nyaman. Ekspresi-ekspresi yang muncul harus disadari sebagai tahap refleksi kritis terhadap diri. Ekspresi penerimaan, misalnya, dapat memaksa setiap agama untuk mempertimbangkan kembali ajaran tradisionalnya dan menyusun kerangka baru melalui pertanyaan dari dialog yang berlangsung. Hal tersebut menawarkan refleksi dan pengalaman yang lebih berkembang dalam beragama, serta dapat menjadi kesempatan belajar dan bertumbuh dalam iman.

Dialog interreligius tidaklah seperti kegiatan misi, yang mengandaikan adanya kemungkinan pertobatan. Dialog ini mengandaikan tindakan untuk sama-sama bersaksi meyakinkan yang lainnya, bukan seperti kegiatan misi yang bersifat satu arah saja. Misi lebih merupakan agenda eksklusif agama. Titik perbedaan ini menjadi penting untuk memurnikan isi kesaksian dalam konteks dialog bersama, dan juga dalam konteks misi masing-masing agama. Dari hal tersebut kemudian akan dilihat peluang-peluang kesaksian bersama dalam konteks pluralitas agama. Setiap agama, perlu memiliki pandangan bahwa dunia ini beragam dan dapat ditemukan kekuatan bersama untuk membangun diri dan dunia yang lebih baik. Paul Knitter menegaskan bahwa dialog tidak akan dapat terjadi apabila setiap pihak datang dengan klaim kebenaran absolut atau kebenaran yang sifatnya final. Menurutnya, dialog interreligius adalah perjumpaan dan percakapan di antara mereka yang mempunyai cara pandang yang tidak memiliki kebenaran final dan tidak menganggap diri sebagai pemenang berkaitan dengan kebenaran. ${ }^{18}$

18 Paul F. Knitter, No Other Name?, (London: SCM Press, 1985), 208-209. 


\section{Kesaksian dalam Teologi Agama-Agama}

Gagasan kesaksian mengenai kebenaran sebuah agama umumnya didasarkan pada keyakinan yang absolut dan final. Paham demikian dapat membawa agama pada sikap arogan. Sikap demikian membuat banyak pemeluk agama memilih bungkam terhadap dialog. Namun demikian, kesaksian dapat mengambil bentuk dan cara yang lain, tergantung pada pribadi-pribadi yang menjalankan teologi agama-agama. Pribadi yang mengakui adanya kebenaran dalam agama lain akan lebih bersifat terbuka terhadap pihak lain. Bagaimanapun, kesaksian juga memainkan peran atau seharusnya memiliki peran sentral dalam teologi agama-agama.

Setidaknya, terdapat tiga aliran yang berkembang dalam teologi agama-agama berkaitan dengan doktrin kebenaran dan keselamatan. Pertama, yang bersifat tradisional dan melihat keselamatan hanya dimiliki oleh satu agama. Ini disebut sebagai sikap eksklusif. Contohnya tampak dalam paham gereja yang lama sekali berpegang pada semboyan extra ecclesiam nulla salus (di luar gereja tidak ada keselamatan). Semboyan ini menyiratkan makna bahwa keselamatan hanya dapat dicapai apabila orang lain menjadi anggota gereja dan mengakui Yesus Kristus sebagai juru selamat.

Kedua, sikap beragama yang inklusif, atau aliran inklusivisme, mendapati elemen keselamatan dalam agama lain. Sikap ini mendorong pembaruan, yakni sudah mempertimbangkan posisi agama lain dalam keselamatan. Dalam gagasan kristiani, teori ini disebut teori pemenuhan, dengan dasar pemahaman bahwa setiap manusia haus akan yang ilahi dan kehausan ini dipenuhi dalam satu titik, yaitu Yesus Kristus. Dalam paradigma itu, kekristenan dilihat sebagai titik puncak sedangkan yang lain dilihat sebagai persiapan wahyu Allah dalam Yesus Kristus. ${ }^{19}$

Ketiga, yang bersifat pluralis, di dalam paradigma ini keselamatan dilihat sebagai milik semua agama. Dalam paradigma pluralisme agama, keberagaman tidak hanya dipandang sebagai fakta, melainkan dilihat juga sebagai kehendak Tuhan yang mengomunikasikan diri kepada manusia dalam konteks berbeda-beda. Perbedaan konteks tersebutlah yang menjadi sumber penyebab perbedaan penafsiran atas Tuhan yang mengomunikasikan diri. Menurut seorang teolog pluralistis, Perry Schmidt-Leukel, tradisi agama-agama besar sepakat bahwa "realitas transenden sesuai dengan hakikat-Nya mengatasi segala kemampuan manusia untuk menangkap dan melukiskan-Nya". Meskipun demikian harus tetap dapat dikatakan bahwa realitas transenden yang tak terbatas itu dapat mewahyukan diri

9 Leonardus Samosir, Agama dengan Dua Wajah: Refleksi Teologis atas Tradisi dan Konteks (Jakarta: Obor, 2009), 89. 
kepada kesadaran manusia yang terbatas. ${ }^{20}$

Di dalam paradigma tersebut juga ada pemahaman akan Tuhan yang mahabesar tidak dapat ditampung dalam satu wadah tertentu, sebab Tuhan jauh lebih besar dari apa yang ditangkap oleh manusia. ${ }^{21}$ Argumen aliran eksklusivisme dan inklusivisme melahirkan ketidakpuasan, karena masih mengandung paham tentang keselamatan yang dibentuk oleh setiap agama, lalu berusaha untuk mendikte paham agama lain. Beberapa teolog dari gereja Katolik maupun gereja Protestan ada yang tidak menyetujui eksklusivisme maupun inklusivisme. Eksklusivisme dianggap mengandaikan bahwa kebenaran utuh dipegang oleh gereja dan inklusivisme dianggap menghapus fungsi agama nonkristen dalam keselamatan. Pandangan ini dianggap masih tidak tulus sebab belum dapat menjawab pertanyaan di mana posisi agama-agama lain dalam konsep keselamatan kristiani. Ketidakpuasan tersebut melahirkan pemikiran dan paradigma baru untuk tetap saling merangkul satu sama lain, misalnya pluralis-teosentris yang berpusat pada Allah. ${ }^{22}$

Berbagai sumber iman yang dimiliki agama umumnya ditulis setelah adanya iman dan kepercayaan akan keselamatan sehingga semua sumber iman religius selalu melihat keselamatan sebagai miliknya sendiri. Dalam rangka menjembatani keadaan afirmasi-negasi sebagai pola paham kebenaran absolut tentang doktrin agama, pendekatan teologi agama-agama dengan orientasi pada kesaksian dan pengalaman iman yang riil dalam dialog sebenarnya dapat membantu mengatasi pendapat-pendapat yang sifatnya a priori atau pengetahuan yang tidak berdasarkan pengalaman,fakta, dan doktrinal. Pendekatan seperti ini dapat mendekati agama lain dengan keterbukaan dan penerimaan yang besar.

Fokus dari kesaksian dalam teologi agama-agama juga adalah memberi kesaksian kepada kepercayaan orang lain tanpa membuat penilaian mengenai ada tidaknya kebenaran dalam agama lain. Dialog interreligius tentu bukanlah sebuah usaha untuk menyatukan semua agama, melainkan untuk melihat realitas pluralitas yang tidak bisa dipungkiri dari dunia ini. Seperti dikatakan E. Schillebeeckx, "secara logis dan praktis, multiplisitas lebih penting daripada kesatuan". Keragaman agama bukan suatu keburukan yang harus dihilangkan, melainkan suatu kekayaan yang harus diterima dan dinikmati oleh semua. Hal yang terpenting bukanlah membentuk suatu

20 Adrianus Sunarko, "Kekristenan Inklusif atau Pluralis? Diskusi dengan Edward Schillebeeckx," dalam Melintas: Jurnal Filsafat dan Teologi 31, no. 1 April (2015): 15-16.

21 Jacques Dupuis, Toward a Christian Theology of Religious Pluralism (Maryknoll, New York: Orbis, 1997), 386-387.

22 Leonardus Samosir, Agama dengan Dua Wajah, 89. 
agama tunggal, melainkan menghadirkan suatu komunitas dialogis antara berbagai komunitas. ${ }^{23}$

Setiap agama juga perlu menghidupkan paham agnostisisme dalam kaitannya dengan pandangan terhadap konsep dogma dan doktrinal tentang keselamatan yang ada dalam agama lain. Paham ini membantu menyadarkan setiap pihak bahwa ia tidak bisa mengetahui secara baik mengenai hadir ataupun absennya kebenaran dalam tradisi agama lain. Setiap pihak boleh mengharapkan bahwa kebenaran tersebut dapat saja muncul dari pengajaran dan praktik yang dihidupi agama lain. Untuk itulah, perlu adanya keterbukaan terhadap agama lain. Keterbukaan mengandaikan adanya sikap penuh perhatian dan keyakinan bahwa hal tersebut bisa mendatangkan pencerahan atau pengayaan. Hal ini nampak dalam dialog oikumenis antara gereja-gereja Kristen. Disebutkan berbagai contoh dialog yang bagi O'Gara disebut sebagai pertukaran rahmat (gift exchange). ${ }^{24}$

\section{Peran Kesaksian dalam Teologi yang Interkultural dan Teologi Perbandingan Agama}

Teologi jika hendak tetap hidup maka harus dilakukan secara interkultural dan kontekstual. Kekristenan pada awalnya juga mengadopsi sepenuhnya tradisi Yahudi dan dekat dengan tradisi Palestina. Seiring berjalannya waktu, terdorong oleh kegiatan misioner yang dilakukan oleh Rasul Paulus, kekristenan berpindah dari dunia Mediterania ke dunia Yunani sebagai wadahnya. Oleh karena misi itu, kekristenan kemudian tidak dapat menghindar dari praktik asimilasi dan penyesuaian diri dalam konteks budaya Yunani dan filsafat Yunani.

Dengan kata lain, di mana pun eksistensi kekristenan ada, kekristenan akan selalu berusaha kontekstual dan mengambil bentuk dalam bahasa dan kebiasaan dari kebudayaan yang beranekaragam. Aloysius Pieris mengatakan, tidak ada agama yang transenden hadir dalam bentuknya yang paling murni atau terpisah dari cara berpikir, merasa, berbicara, dan bertindak dari manusia. Meskipun agama tersebut mengklaim memiliki dimensi keunikan dan universalitas, agama-agama tetap tidak bisa melepaskan diri dari kenyataan bahwa telah terjadi simbiosis antara unsur supranatural dalam tradisi religius tersebut dengan dunia natural dalam konteks di mana tradisi religius tersebut hidup.

Eksistensi agama-agama dengan tradisi religius dan paradigma teologisnya, akan selalu dihadapkan pada bahasa dan idiom kultural di mana

\footnotetext{
Paul F. Knitter, Pengantar Teologi Agama-Agama (terj.) (Yogyakarta: Kanisius, 2008), 7-9.

24 Margareth O'Gara, "Recieving Gift in Ecumenical Dialogue," dalam Receptive Ecumenism and Call to Catholic Learning, Paul Murray ed. (New York: Oxford University Press, 2008), 26-37.
} 
ia eksis, di situ agama ditantang untuk menyesuaikan diri dengan bentuk kultural sebagai tempat serta panggilan bagi agama untuk mengekspresikan dirinya. Itulah sebabnya, bagi Aloysius Pieris, teologi harus kontekstual terutama dalam konteks Asia yang ditandai dengan pluralitas agama dan juga situasi kemiskinan. Oleh karenanya, makna keselamatan juga harus disesuaikan dengan konteks. Baginya, makna keselamatan teologi kristiani adalah melayani orang miskin dan menjalin relasi yang damai dan rukun dalam konteks keragaman agama, sebab itulah yang menjadi konteks Asia. ${ }^{25}$ Teologi harus dan hanya dapat dilakukan dengan cara interkultural dan kontekstual. Kalau tidak, teologi mempunyai peluang untuk menjadi hanya sekadar ilmu bahan khotbah. Karenanya, teologi itu harus diterjemahkan terus-menerus di dalam dunia kultural manusia yang terus berubah.

Saat ini kita telah memasuki era perjumpaan tradisi kultural dan religius yang plural. Situasi ini ditandai dengan tingginya intensitas perjumpaan dan transformasi yang terjadi bagi kedua belah pihak. Dalam konteks itu, sebagai orang Kristen kita diajak untuk dapat melihat dan memperteguh iman kita melalui bahasa, tata cara ibadat, tradisi spiritual yang berbeda, dan dapat menerima hal tersebut sebagai hasil pengayaan pada iman kita. Hal ini tidak terjadi pada kekristenan saja, tetapi juga pada tradisi religius lainnya.

Dalam prinsipnya, terlebih - di dalam praksis - agama Hindu, Buddha, dan Islam dan lain sebagainya, sesungguhnya memuat imperatif iman untuk menyebarkan kasih dan kebaikan. Meski ada kesamaan imperatif iman dalam berbagai tradisi religius, bisa saja ini memunculkan ketakutan akan relativisme. Akan tetapi paradigma relativis demikian perlu dikritik juga, meminjam apa yang dikatakan Paul Knitter, bahwa pengertian dari kata sesungguhnya (truly) tidak harus diikuti dengan kata hanya satu-satunya (only). ${ }^{26}$ Masalahnya, kecenderungan setiap agama adalah berorientasi pada kata the only one dan ini yang seringkali menjadi akar masalah terjadinya konflik agama.

Berteologi secara interkultural mungkin bukan sesuatu yang baru pada dirinya sendiri, namun kegiatan itu menunjukkan adanya kesadaran diri. Saat ini kita membutuhkan perspektif dan metodologi baru untuk mengubah teologi menjadi sebuah proyek yang kontekstual dan transformatif. Hal ini sangat dibutuhkan untuk mengatasi dikotomi antara agama dengan dunia dan paradigma sekuler yang terus berkembang. Tantangan untuk menyeimbangkan kedua hal ini tampak dalam relasi antara norma-norma etika dengan nilai-nilai yang dijunjung tinggi dalam setiap tradisi religius.

\footnotetext{
25 Aloysius Pieris, An Asian Theology of Liberation (New York: Orbis Books, 1992), 74-75.

26 Paul Knitter, No Other Name? 184-186.
} 
Penelitian Djoko Prasetyo menegaskan bahwa berteologi dalam konteks interkultural adalah sebuah doing theology yang berarti bahwa misi dalam teologi tidak sekadar paralel satu arah dari teologi menuju pada konteks, melainkan melibatkan semua elemen dalam konteks. Dengan demikian konteks bukanlah target melainkan pelaku bersama. Kontekstualisasi yang ideal dengan demikian adalah kontekstualisasi yang interkultural membangun teologi bersama-sama dengan konteksnya setelah proses saling mendengarkan dan di situlah teologi bukan hanya dapat berdaya transformatif serta memberikan solusi melainkan juga mengajak dan melibatkan semua elemen untuk masuk dalam wacana ikatan bersama untuk saling membantu, belajar, dan merayakan. ${ }^{27}$

Meskipun transformasi dan pergeseran paradigma dari yang eksklusif menuju inklusif itu telah terjadi, akan tetapi proses inkulturasi berjalan lambat. Sepanjang tahun 1950-1970 perdebatan tentang inkulturasi hanya mengenai pemisahan antara apa yang menjadi tradisi kekristenan dan hal apa yang berasal dari unsur kultural untuk praktik religius. Sedangkan pada tahun 1980-an perdebatan bergeser pada sikap kritis atas dominasi kultur Barat dalam pembentukan nilai kristiani, contohnya adalah monogami. Terlebih kini, ketika para teolog menyadari bahwa nilai-nilai kristiani menemukan ekspresinya yang konkret di dalam norma-norma moral, proses teologi secara interkultural juga menyoroti keterbatasan sudut pandang tradisi teologi kristiani.

Teolog-teolog seperti Benezet Bujo, Jean Marc Ela, Mercy Oduyoye, dan Kwok Pui Lan menantang kekristenan untuk berpikir secara berbeda mengenai cara berpikir teologi, terutama mengaitkannya dengan etika. Sesungguhnya jika kita mulai berteologi secara kristiani dan etika secara bersamaan, kita dapat melihat dengan jelas bahwa wawasan-wawasan teologis dan beretika secara kristiani dapat bertentangan ataupun sejalan dihadapkan pada partikularitas dalam kultur tertentu dan bersifat sementara. Itu sebabnya, kita seharusnya lebih dapat menghargai kenyataan bahwa pencarian sebuah pemahaman teologis selalu terkait dengan keberadaan seseorang yang terikat dengan konteks tertentu, yang sama sekali berbeda dengan yang lainnya.

Teologi perbandingan agama sebagai sebuah ilmu juga sering dilihat sebagai bentuk sistematik dari dialog interreligius. Ranahnya mencakup studi tentang sumber iman, sejarah dan praktik dari agama lain, sehingga dapat memunculkan keunikan suatu tradisi agama. Usaha ini bisa dikatakan sebagai usaha "iman mencari pengertian" (dalam semboyan Anselmus:

\footnotetext{
27 Djoko Prasetyo, “Konvivenz' dan Theologia Misi Interkultural Menurut Theo Sundermeier," dalam Gema Teologika: Jurnal Teologi Kontekstual E Filsafat Keilahian 32, no. 1 April (2008), 1-20.
} 
fides quaerens intellectum), namun dalam konteks perbedaan agama. Tidak seperti pengertian dialog pada umumnya, teologi perbandingan agama tidak mengisyaratkan dialog dengan seorang teman bicara, melainkan menaruh fokus pada studi teks, sistem filsafat, ritual, ataupun praktik etika dari agama tertentu. Namun demikian, dialog jenis ini sebenarnya memiliki tujuan yang sama, yakni belajar dari agama lain. Belajar dapat dilakukan dengan berbagai cara, seperti: penemuan sesuatu yang baru, penemuan kesamaan dan perbedaan yang signifikan, atau juga melalui rasa hormat pada ajaran atau praktik yang menguatkan keyakinan sebuah agama.

Dalam teologi perbandingan agama, terdapat persoalan mengenai dua istilah yang saling berkaitan sekaligus berlawanan yakni unsur pernyataan iman dengan teologi perbandingan agama. Keith Ward, misalnya, membuat pembedaan antara keduanya. Baginya, pernyataan iman adalah eksplorasi keseluruhan sistem keyakinan berdasarkan pewahyuan ilahi yang dihidupi oleh sebuah agama, sedangkan teologi perbandingan ialah sebuah teologi yang bukan bertujuan untuk membela ajaran agama tertentu, melainkan sebuah disiplin ilmu yang berusaha mencari nilai hakiki dan tujuan hidup manusia dari berbagai tradisi keagamaan yang ada. ${ }^{28}$ Dengan pembedaan ini, dapat dikatakan bahwa teologi perbandingan agama sebenarnya merupakan usaha pencarian kebenaran oleh individu tertentu, bukan sebuah sistem dari lembaga keagamaan. Sampai pada titik ini, muncul pertanyaan mengenai perlunya teologi perbandingan agama sebagai sebuah diskursus teologi. Siapa yang terlibat dalam pembicaraan ini, serta atas dasar apa kita dapat mengikutsertakan pengajaran teologi yang berbeda ini?

Cathrine Cornille mengatakan teologi perbandingan agama adalah juga teologi yang berpusat pada pengakuan dan kesaksian iman. Teologi perbandingan agama tidak hanya menekankan pembelaan iman, melainkan juga keterbukaan pada pihak lain yang bisa jadi akan mencerahkan dan memperkaya pemahaman sebuah agama. Pendekatan teologi perbandingan agama adalah dalam bentuk kesaksian. Dialog tidak serta-merta harus bersifat verbal dan lawan bicaranya pun bukan melulu dari pihak lain, melainkan juga pertama-tama sesama anggotanya sendiri. Melalui dialog dengan yang lain, anggota dari sebuah agama bisa diperkuat dan diperdalam imannya. ${ }^{29}$

28 Keith Ward, Religion and Revelation: A Theology of Revelation in the World's Religions (Oxford: Oxford University Press, 1994), 40.

29 Cathrine Cornille, Meaning and Method in Comparative Theology (Chichester: Wiley-Blackwell, 2019), 83-87. 
Pencarian kebenaran terhadap agama lain didasarkan pada pertanyaan dan isu-isu yang hidup dan relevan dalam tradisi lain. Pencarian ini merupakan suatu pencarian tanpa batas. Berbagai unsur dalam setiap agama dapat dibandingkan satu sama lain. Hasil perbandingan ini bisa menghasilkan sesuatu yang penting dan menarik. Namun pertanyaannya, bagaimana tindakan ini dapat memperkaya tradisi sendiri? Perlu diketahui, perbandingan agama yang dilakukan tidak hanya menyangkut perbandingan ajaran, melainkan juga keterlibatan dialogis para teolognya, yang dengan penuh pengharapan menerima manfaat berupa insight dan refleksi teologis pihak lain yang lebih luas. Tema pembicaraan dalam kegiatan perbandingan ini pun tidak hanya dibatasi pada berbagai persoalan aktual saja, melainkan juga berbagai tema lain yang bisa dijadikan starting point untuknya. Dalam teologi perbandingan agama, keuntungan tidak selamanya hanya dirasakan pihak yang berdialog. Anggota dari satu agama pun akan mendapatkan manfaat dari kegiatan ini, yakni semakin mendalami kebenaran ultima yang diimani.

\section{Pentingnya Kesaksian dan Dialog Interreligius Masa Kini}

Sejatinya iman mengarahkan manusia melihat sesama dan semesta untuk dihargai dan dikasihi. Melalui iman kepada Allah yang menciptakan alam semesta dan seluruh umat manusia, setiap umat beriman dipanggil untuk mendemonstrasikan dan mewujudkan persaudaraan manusia dengan saling melindungi sesama manusia dan seluruh alam semesta, terutama berkaitan dengan perkara kemanusiaan dan perkara ekologis yang dihadapi oleh peradaban masa kini. ${ }^{30}$ Dalam arti ini kesaksian dalam dialog yang dimaksud adalah komunikasi yang saling menghormati tentang kekhasan tradisi iman yang memuat nilai-nilai kebenaran autentik dari setiap tradisi religius. ${ }^{31}$ Pertanyaan penting bagi kesaksian dan dialog dalam agama adalah: apa yang penting untuk keselamatan, kesejahteraan, kedamaian, dan kebaikan semua umat manusia dan keutuhan alam ciptaan? Pertanyaan terakhir tersebut adalah upaya pencapaian nilai transendental sebagai dasar bersama untuk perjumpaan yang dilandasi dengan sikap persahabatan serta persaudaraan yang memiliki keprihatinan bersama dalam perkara kemanusiaan dan lingkungan yang masih terus kita hadapi dalam konteks kehidupan bersama saat ini. Kita dapat belajar dari Levinas yang mengatakan bahwa relasi dengan yang lain (stranger) adalah undangan (appeal)

Bdk. Departemen Dokumentasi dan Penerangan Konfrensi Wali Gereja Indonesia, Dokumen tentang Persaudaraan Manusia untuk Perdamaian Dunia dan Hidup Beragama (Jakarta: Dokpen KWI, 2019): 6.

31 Understanding Religious Relations, David Cheetham ed. (Oxford: Oxford University Press, 2013), 212. 
untuk berbuat etis dan terwujud dalam hal konkret. Perjumpaan mengundang tanggung jawab untuk menanggapi dan menerima orang lain. ${ }^{32}$ Pada konteks tersebut, ketika identitas diri berhadapan dengan yang lain, justru identitas diri tidak menjadi tertutup. Dengan demikian, perjumpaan adalah peluang dan kunci untuk menciptakan wacana komunikasi yang berorientasi pada satu sama lain. Perjumpaan seperti itu merumuskan sesuatu yang baru serta kemampuan saling mendengarkan. Di sini, listening adalah kunci bersama untuk merawat kebersamaan di dalam perbedaan. ${ }^{33}$

Dalam bersaksi dan berdialog, agama-agama ditantang untuk selalu menjadikan tema kemanusiaan dan lingkungan dalam prioritas sikap serta orientasi moral yang utama. Agama-agama juga ditantang untuk menciptakan peradaban baru yang menjadikan bumi menjadi tempat yang layak huni bagi manusia dan seisi alam ciptaan. Perancangan dan penghijrahan dari keadaban lama menuju keadaban baru bersumber dari pertimbangan kemajuan teknologi yang mutakhir, era digital yang canggih, dan kemajuan ilmiah. Perkembangan media sosial juga bersumber dari pertimbangan masih besarnya tingkat kemiskinan, ketidakadilan sosial, perang, korupsi, genjatan senjata, kemerosotan moral, ekstremisme, terorisme, fundamentalisme, bahkan kematian karena penyakit dan tragedi wabah Covid-19 yang saat ini kita hadapi secara global.

Latar belakang pertimbangan tersebut membuat agama-agama perlu saling merangkul dan berjalan di garda terdepan untuk melawan perkara-perkara yang mengancam kemanusiaan kita. Di tataran ini telah dirumuskan dalam sebuah dialog dan keprihatinan bersama terhadap halhal yang mengancam kemanusiaan serta masalah-masalah lingkungan. Demikian juga yang telah menjadi pokok pembahasan di dalam dokumen hasil dialog pertemuan Gereja Katolik Timur dan Barat dengan Al-Azhar al-Sharif dan umat muslim Timur dan Barat yang ditandatangani pada tanggal 4 Februari 2019 di Abu Dhabi, menyatakan bahwa budaya dialog sebagai jalan dalam kerja sama timbal balik dan juga sebagai kode etik dan saling pengertian sebagai metode dan kriteria. ${ }^{34}$ Terutama juga dalam membela kemanusiaan yang terancam oleh pihak-pihak yang memaksakan kehendak demi kepentingan sepihak.

Kesaksian yang penting saat ini perlu didasarkan pada tanggung jawab moral dan iman agar mau terlibat dalam kebijakan yang berpihak terhadap mereka yang tertindas, sakit, dan tersisihkan. Agama-agama di

32 Emmanuel Levinas, Totality and Infinity: An Essay on Exteriority (Dordrecht: Springer Netherlands, 1979), 213.

33 Abi Doukhan, Emmanuel Levinas: A Philoshopy of Exile (London: Bloombury Academic, 2014), 43.

${ }^{34}$ Departemen Dokpen KWI, Dokumen tentang Persaudaraan Manusia untuk Perdamaian Dunia dan Hidup Beragama,10. 
dalam kesaksiannya juga berperan menyerukan dan mengajak pemimpin dunia serta pembuat kebijakan internasional untuk bekerja keras menyebarkan budaya toleransi, kedamaian hidup bersama, intervensi radikal untuk menghentikan pertumpahan darah dari orang-orang yang tidak bersalah, mengakhiri peperangan dan konflik berkelanjutan, kerusakan lingkungan, kemerosotan moral, dan budaya. ${ }^{35}$ Ditambah lagi tantangan bersama yang dihadapi saat ini, yakni pandemi Covid-19 dan konflik agama yang terjadi di India yang menimbulkan banyak korban meninggal.

Di tengah situasi demikian kesaksian iman akan menjadi nyata bukan hanya dalam tataran iman teoritis, melainkan juga dalam praksis nyata. Itulah sebabnya, setiap umat beriman lintas agama ditantang untuk menyerukan nilai perdamaian, saling merangkul dalam menghadapi tantangan peradaban saat ini, sehingga menciptakan keselamatan bagi semua. Dari perspektif ini, keselamatan tidak lagi eksklusif maupun inklusif, melainkan semua manusia berhak mendapatkan keselamatan yang berdampak nyata. Dengan kata lain, keselamatan harus dimulai dari lingkungan kita dan sejatinya keselamatan itu adalah cinta.

Peradaban masa kini juga ditandai dengan situasi ketidakadilan terutama yang tampak dalam pengelolaan dan distribusi sumber daya alam yang cenderung tidak adil, hanya menguntungkan segelintir orang kaya yang mempunyai kuasa, dan hal tersebut seringkali merugikan mereka yang kurang mampu dan lemah. Hampir di setiap penjuru bumi dapat ditemukan perkara-perkara demikian. Ada banyak anak-anak mati kelaparan karena perang dan krisis politik, penimbunan bahan-bahan pokok demi keuntungan ekonomis yang besar terutama dalam situasi pandemi Covid-19 saat ini. Lebih dari itu, kita masih melihat kesombongan dalam kesaksian iman sebagai dalih untuk menolak arahan pemerintah. Iman memberikan pengertian, bukan untuk ditafsirkan dalam ketaatan yang tidak dikuti pertimbangan akal budi. Kesaksian iman juga perlu sejalan dengan ketaatan akal budi, agar kesaksian iman tidak disalahgunakan untuk kesombongan. Kesaksian iman yang autentik adalah kesaksian yang berdampak bagi keselamatan diri dan orang lain.

Dalam konteks ini penting membangkitkan kesadaran beragama dan juga terutama bagi generasi baru yang mungkin dapat menjadi penjajak awal keadaban baru. Hal ini dapat diupayakan dengan mengembangkan pendidikan moral dan ajaran agama. Indonesia sebagai negara religius (religious nation state) yang berdasarkan sila Ketuhanan yang Maha Esa mempunyai salah satu tugas utama, yaitu menjadikan cara hidup bersama

35 Ibid., 11. 
dan bernegara di tengah situasi yang berbeda sebagai proses sakralisasi diri dengan menimba moral ketuhanan berdasarkan spiritualitas dalam agama dan menjadikannya sebagai dasar hidup bernegara serta hidup bersama mereka yang berbeda, yang lemah, dan yang berkekurangan. ${ }^{36}$

Generasi masa kini dihadapkan pada tantangan yang juga berasal dari ketegangan problematika konflik agama, ditambah lagi masalah yang demikian mudah disulut di media sosial. Dunia media sosial juga berpengaruh terhadap dunia riil. Kebencian yang ditebar di dalam media sosial membuat kehidupan sebelumnya yang saling berdampingan dapat berubah menjadi saling curiga. Sebelumnya kita hidup damai, kini menjadi tercerai-berai. Di dalam situasi demikian ada saja yang mengambil kesempatan dan memancing di air keruh, atau dengan kata lain ada provokator atau siluman yang memproduksi sebanyak-banyaknya hal yang dapat menyebabkan keretakan dan konflik agama di tengah masyarakat demi kepentingan tertentu. ${ }^{37} \mathrm{Hal}$ ini rentan dihadapi saat ini.

Tujuan pertama dari beragama adalah percaya pada Allah yang memberi anugerah kehidupan. Ini adalah anugerah yang tidak seorang pun berhak untuk mengambil, mengancam, atau memanipulasi demi kepentingan dirinya sendiri atau kelompoknya. Setiap orang harus menjaga anugerah kehidupan ini dari awal hingga akhir. Agama tidak boleh memprovokasi peperangan, sikap kebencian, permusuhan, dan ekstremisme. Realitas tragis macam ini merupakan akibat dari penyimpangan ajaran agama. Hal tersebut adalah hasil dari manipulasi politik agama-agama dan penafsiran yang dibuat oleh kelompok-kelompok yang mengambil keuntungan dari kekuatan sentimen keagamaan di hati para pemeluknya dan membuat mereka bertindak dengan cara yang tidak berkaitan dengan kebenaran agama. Ini dilakukan demi tujuan yang bersifat politis, ekonomi, duniawi, dan picik. ${ }^{38} \mathrm{Hal}$ ini ditegaskan dengan sangat kuat dan jelas di dalam pertemuan Paus Fransiskus dengan Imam Besar Al-Azhar Ahmad Al-Tayyeb di Abu Dhabi. Di dalam pertemuan tersebut ditegaskan bahwa kesaksian bersama umat beragama saat ini adalah berhenti menggunakan agama untuk menghasut orang kepada kebencian, kekerasan, ekstremisme, dan fanatisme. Umat beragama perlu menahan diri menggunakan nama Allah untuk membenarkan tindakan pembunuhan, pengasingan, terorisme, dan penindasan. Sebab berdasarkan kepercayaan bersama, laki-laki dan

36 Sekretariat Jenderal MPR-RI, Empat Pilar Kehidupan Berbangsa dan Bernegara (Jakarta: Sekretariat Jenderal MPR-RI, 2012), 45-50.

37 Agus Rachmat, "Interreligious Conflict and Reconciliation in Indonesia," dalam Melintas: Jurnal Filsafat dan Teologi 17, no. 52-53 (2001): 66-67.

38 Departemen Dokpen KWI, Dokumen tentang Persaudaraan Manusia untuk Perdamaian Dunia dan Hidup Beragama, 16. 
perempuan diciptakan bukan untuk dibunuh atau untuk saling berkelahi, atau disiksa atau dihina. Allah yang mahakuasa tidak perlu dibela oleh siapa pun dan tidak ingin nama-Nya digunakan untuk meneror manusia. ${ }^{39}$

Kesaksian bersama yang penting adalah melakukan ajaran-ajaran autentik yang mengakar dan mendalam dari setiap agama dan penganutnya, seperti hidup dalam perdamaian, persaudaraan yang harmonis, membangun kebijaksanaan kasih, menciptakan keadilan, dan juga terutama mendidik generasi-generasi muda dalam kesadaran beragama dan nilai-nilai agama agar generasi berikut terhindar dari ranah pemikiran materialistis, kebijakan yang berbahaya akan keserakahan dan ketidakpedulian terhadap kehidupan dan lingkungan. ${ }^{40}$

Melalui dialog, setiap agama diajak saling bersaksi dengan ajaran autentik agama masing-masing agar bersama-sama saling merangkul membangun kekuatan untuk memberi daya transformatif bagi realitas yang chaos serta menyediakan dan menciptakan keadaban baru yang religius dan manusiawi dalam konteks keberagaman agama. Dialog antarumat beragama mempunyai arti bahwa kita berkumpul bersama dalam nilai-nilai rohani yang autentik serta berpihak pada nilai kemanusiaan, kehidupan bersama, dan lingkungan hidup untuk menjunjung tinggi keutamaan moral sebagai tujuan dari agama. Inilah tugas bersama dan menjadi dasar bagi semua umat beragama untuk bersaksi tentang keutamaan moral yang autentik.

Pada akhirnya dialog itu sejatinya adalah bagian dari kesaksian iman yang tidak dapat dipisahkan. Dalam konteks pluralitas agama, peran dialog adalah jalan perjumpaan untuk saling merangkul satu sama lain, saling belajar, dan saling merayakan, serta memperdalam tradisi religius masing-masing. Di dalam dialog tersebut kesaksian iman, kekhasan iman, dan nilai-nilai autentik sebuah identitas penting untuk disuarakan sehingga peserta dialog saling mendengarkan satu sama lain. Kesaksian iman dalam dialog tidak untuk disembunyikan tetapi untuk diwartakan dengan ramah sehingga membuka peluang untuk saling mendengar, saling belajar, saling menginspirasi, membuka ruang interpretasi dan melihat diri sendiri melalui kesaksian iman yang lain. Dengan begitu, kesaksian iman di dalam dialog menjadi berkualitas dan berdampak transformatif terutama dalam relasi antarumat beragama. Dengan kata lain, relasi antara dialog dan kesaksian iman adalah relasi yang saling memenuhi satu sama lain. Kesaksian iman mendefinisikan dialog dan dialog menjadi ruang perjumpaan kesaksian iman serta nilai autentik yang mengikutinya untuk menemukan bersama titik konvergensi yang berorientasi pada relasi yang damai, saling berbuah

$39 \quad$ Ibid.,16.

40 Ibid., 17. 
serta bertumbuh, dan rukun dalam konteks pluralitas agama.

\section{Kesimpulan}

Kesaksian iman merupakan unsur penting dalam dialog interreligius terutama dalam eksistensi teologi dalam konteks interkultural. Dalam kesaksian yang dimaksud juga mencakup kesaksian terhadap realitas dan pengalaman yang tidak bisa digenggam atau ditunjukkan secara utuh oleh setiap tradisi agama. Hal ini sangat penting mengingat keterbatasan setiap agama dalam memahami kebenaran yang hakiki. Dalam berdialog, terdapat relasi antara tindakan memberi kesaksian dan keterbukaan terhadap yang lain, keyakinan akan ajaran yang autentik dan praktik agama yang bersifat rendah hati untuk mendengarkan pihak lain. Dengan dialog seperti ini, setiap penganut agama akan lebih memahami inti ajaran setiap agama, tanpa adanya justifikasi a priori.

Selain kerendahan hati, setiap agama perlu juga bersifat agnostik-teologis yang melihat diri dan ajarannya tidak bisa mencapai kebenaran secara mutlak sehingga perlu berdialog dengan pihak lain agar mampu memahami kebenaran tersebut. Dengan kesadaran seperti ini, dialog tidak akan dimulai dengan mencari unsur-unsur keselamatan setiap agama untuk diperbandingkan ataupun dikutuk, melainkan lebih pada tindakan bersaksi untuk menemukan jawabannya sendiri dan berdampak transformatif bagi realitas kemanusiaan. Dengan peran itu, kesaksian iman agama-agama dapat menjadi garda terdepan untuk menciptakan keadaban baru yang rohani dan manusiawi, sehingga bumi yang kita cintai menjadi tempat yang lebih layak huni bagi seisi ciptaan.

Kajian kritis yang menjadi catatan dalam konteks kesaksian dalam dialog adalah perlunya membedakan antara misi dan dialog, namun tidak untuk dipisahkan. Misi berarti mempertahankan ajaran dan pengalaman iman, sedangkan dialog adalah keterbukaan untuk mengenal dan berbagi satu sama lain. Dalam dialog, kesaksian yang disampaikan adalah kesaksian akan keyakinan imannya, dan salah satu yang terpenting ialah kesediaan dan kerendahan hati untuk mendengar dan berbicara. Tidak ada misi yang tidak berdialog. Semua tindakan misi mengandalkan dialog dengan pihak lain. Misi dan dialog adalah dua hal yang berjalan bersama. Misi menekankan unsur dialogis antara berbagai agama dalam wujud kesaksian. Dialog tetap tidak bisa menggantikan perintah bermisi, namun melengkapi tindakan ini melalui pencarian akan kebenaran serta kesadaran akan kedinamisan bersama.

Pencarian akan kebenaran hanya merupakan sebuah tindakan rekonstruksi dan bukannya tindakan menciptakan ulang kebenaran karena 
kebenaran sudah ada sejak awal mula dan bersifat tetap. ${ }^{41}$ Dialog yang hanya berbagi informasi kebenaran tentang Allah dan doktrin tentang kebenaran akan Allah mungkin tidak lagi relevan. Untuk itu, dialog diadakan dengan tujuan merekonstruksi kebenaran yang hakiki itu secara lebih baik lagi. Setiap umat beragama dan agama itu sendiri ditantang untuk mengubah paradigma dalam konteks pluralitas agama.

Dalam kesaksian bersama untuk melawan tindakan destruktif pada kemanusiaan, keragaman dan keutuhan alam ciptaan sudah menjadi titik terang afirmasi keragaman dan sekaligus terjalinnya relasi yang baik di antara berbagai agama yang ada di dunia ini. Untuk memenuhi beberapa harapan tersebut artikel ini mengajukan beberapa rekomendasi. Pertama, setiap agama perlu membuka diri dan menambah program dialog antarumat beragama dari tingkat bawah sampai ke atas. Kuantitas perjumpaan di dalam dialog perlu ditingkatkan dengan harapan dapat membangun relasi satu sama lain.

Kedua, revisi isi dialog. Selama ini isi dialog cenderung hanya berusaha untuk saling mengerti dan menghindari terjadinya konflik serta mengesampingkan tempat untuk saling bersaksi. Isi dialog perlu dirancang dengan berorientasi pada penemuan titik konvergensi pengalaman dan kesaksian iman. Artinya, di dalam dialog perlu diberi ruang untuk saling bersaksi tentang iman dan nilai-nilai autentik agar dapat saling belajar dan memenuhi diri melalui pengalaman pihak lain.

Ketiga, kesaksian iman di dalam dialog interreligius dan teologi interkultural perlu dikaji lebih kritis. Artinya, tema ini penting untuk dikembangkan di ruang-ruang kampus yang mengkaji tentang agama mengingat konteks pluralitas agama yang dapat menjadi sumber kekuatan tetapi juga dapat menjadi konflik. Keempat, pentingnya untuk membuat program dialog aksi. Aksi bersama mendesak setiap tradisi religius untuk saling merangkul dan bekerja sama menanggulangi masalah kemanusiaan dan lingkungan. Itu sebabnya dalam dialog perlu untuk merancang keterlibatan setiap umat beragama sebagai kesaksian bersama terhadap masalah-masalah sosial. Di sini kesaksian iman dalam dialog berdampak bagi realitas sosial.

Penulis menyadari bahwa terdapat banyak kelemahan di dalam kajian tulisan ini dan penulis terbuka terhadap kritik dan evaluasi yang dapat membangun dan memperkaya tulisan ini. Di dalam tulisan ini juga ada terdapat beberapa tema yang belum dieksplorasi lebih komprehensif misalnya bagaimana hubungan kesaksian iman dalam konteks misi interkultural,

\footnotetext{
${ }^{41}$ Maureen Junker Kenny, “Witnessing or Mutual Translation," dalam Concillium Volume 1 (London: SCM Press, 2011), 112.
} 
bagaimana dialog dalam perspektif tradisi religius masing-masing, serta mengeksplorasi secara komprehensif tema tentang teologi perbandingan agama dalam kajian dialog. Tema yang belum dieksplorasi tersebut terbuka menjadi tema penelitian selanjutnya untuk melengkapi dan memperkaya tulisan ini.

\section{Daftar Pustaka}

Admirand, Peter. Mission in Remission: Concilium 1. London: SCM Press, 2011.

Banawiratma, J.B. \& Abidin Bagir, Zainal ed., Dialog Antarumat Beragama: Gagasan dan Praktik di Indonesia. Jakarta: Mizan Publika, 2010.

Bosch, David J. Transforming Mission, Paradigm Shifts in Theology of Mission. Maryknoll, New York: Orbis Books, 2011.

Cobb Jr.dan John B. Transforming Christianity and the World: A Way beyond Absolutism and Relativism. Maryknoll, New York: Orbis Books, 1999.

Cornille, Cathrine. Interreligious Diaologue. Chichester, UK: John Wiley \& Sons, 2013.

Conolly, Peter, ed. Ragam Pendekatan Studi Agama. Medan: Bina Media Perintis, 2007.

Cornille, Catherine. Meaning and Method In Comparative Theology. Chichester: Wiley-Blackwell, 2019.

Coward, Harold. Pluralisme: Tantangan bagi Agama-Agama. Yogyakarta: Kanisius, 1989.

Cheetham, David ed. Understanding Religious Relations, Oxford: Oxford University Press, 2013.

Departemen Dokumentasi dan Penerangan Konferensi Waligereja Indonesia. Evangelii Gaudium. Jakarta: Dokpen KWI, 2013.

Departemen Dokumentasi dan Penerangan Konferensi Wali Gereja Indonesia. Dokumen: tentang Persaudaraan Manusia untuk Perdamaian Dunia dan Hidup Beragama. Jakarta: Dokpen KWI, 2019.

Doukhan, Abi. Emmanuel Levinas: A Philoshopy of Exile. London: Bloombury Academic, 2014.

Dupuis, Jacques. Toward a Christian Theology of Religious Pluralism. Maryknoll, New York: Orbis, 1997.

Junker Kenny, Maureen. Witnessing or Mutual Translation: Concillium 1. London: SCM Press.

Knitter, Paul F. No Other Name? London: SCM Press, 1985.

Knitter, Paul F. Pengantar Teologi Agama-Agama (terj.). Yogyakarta: Kanisius, 2008.

Levinas, Emmanuel. Totality and Infinity: An Essay on Exteriority. Dordrecht: 


\section{EDY SYAHPUTRA SIHOMBING}

Springer Netherlands, 1979.

O'Collins, Gerald \& Farrugia, Edward G. Kamus Teologi (terj.). Yogyakarta: Kanisius, 1996.

O'Gara, Margareth. "Recieving Gift in Ecumenical Dialogue.” Dalam Receptive Ecumenism and Call to Catholic Learning. Paul Murray ed. New York: Oxford University Press, 2008.

Parihala, Yohanes \& Saptenno, Kritsno. “Dari Kesaksian Iman ke Simbiosis Agama: Mininjau Konsep Dialog Calvin E. Shenk Bagi Perjumpaan Islam-Kristen di Maluku." Religious: Jurnal Studi Agama-Agama dan Lintas Budaya 4, no. 2 (2020): 104-114. Maluku: Universitas Kristen Maluku.

Pieris, Aloysius. An Asian Theology of Liberation. New York: Orbis Books, 1992.

Prasetyo, Djoko. "Konvivenz dan Theologia Misi Interkultural Menurut Theo Sundermeier." Gema Teologika: Jurnal Teologi Kontekstual E Filsafat Keilahian 32, no. 1 (2008): 1-20. Yogyakarta: Fakultas Teologi Universitas Kristen Duta Wacana.

Rachmat, Agus. "Interreligious Conflict and Reconciliation in Indonesia." Melintas: Jurnal Filsafat dan Teologi 17, no. 52-53 (2001): 1-116. Bandung: Fakultas Filsafat Unika Parahyangan.

Samosir, Leonardus. Agama dengan Dua Wajah: Refleksi Teologis atas Tradisi dan Konteks. Jakarta: Obor, 2009.

Sekretariat Jenderal MPR-RI. Empat Pilar Kehidupan Berbangsa dan Bernegara. Jakarta: Sekretariat Jenderal MPR-RI, 2012.

Servaas Wijsen, Frans \& Nissen, Peter. Mission is Must: Intercultural Theology and the Mission of the Church. New York \& Amsterdam: Rodopi, 2002. Setyawan, Heri. "Mencari Arah Baru Dialog dengan Agama lain." Kawistara: Jurnal Ilmiah Sosial dan Humaniora 4, no. 2 Agustus (2014): 111-124. Yogyakarta: Sekolah Pasca Sarjana, Universitas Gadjah Mada.

Sunarko, Adrianus. "Kekristenan Inklusif atau Pluralis? Diskusi dengan Edward Schillebeeckx." Melintas: Jurnal Filsafat dan Teologi 31, no. 1 April (2015): 1-106. Bandung: Fakultas Filsafat Unika Parahyangan.

Tong, Stephen. Teologi Penginjilan. Jakarta: Lembaga Reformed Injili, 1988. Ward, Keith. Religion and Revelation: A Theology of Revelation in The World's Religions. Oxford: Oxford University Press, 1994. 